\title{
BERLIN 1936: THE CREATION OF THE "MYTH" JESSE OWENS
}

\author{
Werlayne Stuart Soares Leite \\ Secretariat of Education of the State of Ceará-SEDUC, Brazil
}

\begin{abstract}
Throughout the twentieth century, the sport has gained much importance in society and sparked interest from various sectors, including the political. Adolf Hitler used the XI 1936 Summer Olympic Games to show the world the strength of Nazi Germany and its rebirth after the defeat in World War I and the impositions of the Versailles Treaty. However, many of the facts historically reported on the 1936 Olympics are contested. The most famous and mythical case of these Olympic Games, and one of the most famous in the history of sport, relates to events that occurred between the American athlete Jesse Owens and the Nazi Führer. The aim of this work is to try to show, as faithfully as possible, as some important facts occurred during this event (the contest between Owens and Long in the long jump; if Hitler snubbed Owens; etc.) that helped create the "myth" around Owens; and to present reports of the global media coverage, analyzing the perpetuation of these mythical reports in current media. As methodology was conducted an ample bibliographical research: reports taken from newspapers of the time and current, books, scientific papers, master's thesis, documentaries, etc. Without claiming to prove a single fact, it is intended to provide insight to the reader to draw their own conclusions.
\end{abstract}

Key words: $\quad$ XI Olympic Games, Long jump, Battle of colors, Luz Long, Adolf Hitler.

DOI 10.1515/afepuc-2017-0010

(C) Acta Facultatis Educationis Physicae Universitatis Comenianae 


\section{Introduction}

"In a time of universal lies, telling the truth is a revolutionary act." (George Orwell)

The sport is now considered one of the greatest social phenomena of the world (Mostaro 2012). This development has made it to assume multiple possibilities, interesting different sectors of society, e.g., educational, political, economic, social, cultural sectors, among others (Maia 2010). The society is facing a phenomenon that, like all social phenomena, it is historically conditioned and culturally determined (Leite 2015).

The 1920s and 1930s were landmarks of sports explosion as a mass phenomenon linked to a new lifestyle - urbanized and dynamic - that hit the most industrialized regions of the world. These regions have seen a revolution that took from the sport its playful character and turned it into a competition plant. This situation was exploited by many countries viewing athletes and national sports teams as an extension of politics (Salun 2012). The first politician who used the sport and the Olympic Games as a market instrument to promote his ideas was Adolf Hitler (Brazilian Olympic Committee [BOC] 2006).

XI. Summer Olympics were held in the city of Berlin, capital of Germany, from $1^{\text {st }}$ to $16^{\text {th }}$ August 1936. The story involving these Games is already well known. Hitler intended, through a monumental organization and the victory of the German athletes, to show the new Germany that was born after World War I, and to demonstrate the power and the strength of its political organization and the state, and especially the attempt to demonstrate the superiority of the Aryan race. These objectives were widely disseminated by the propaganda of the Nazi party through newspapers, radio and cinema (Mostaro 2012). The holding of the Olympic Games would be used to exalt the honor of the German people, shaken by the humiliating impositions of the Treaty of Versailles (Sigoli \& De Rose Jr. 2004).

Throughout the tortured history of sports and politics, one moment has always stood above the others: Jesse Owens's performance at the 1936 Berlin Olympics (Broughton 2009). The AfricanAmerican athlete Jesse Owens, winning several gold medals in the athletic mode, did Hitler`s dream fall apart (BOC 2006). American and black, Owens won four gold medals in the $100 \mathrm{~m}, 200 \mathrm{~m}, 4 \mathrm{x}$ $100 \mathrm{~m}$ relay and long jump. In the latter mode, defeated the German and European record holder, Luz Long, and beat the Olympic record (Mostaro 2012).On the sacred soil of the Fatherland, the master athlete humiliated the master race (Schwartz 2005).

The shorthand version of the story that generations of Americans (and many peoples in the world) have learned over the past 80 years that Jesse Owens was good, while Nazi Germany was evil (Goldman 2009). This was the background for the 1936 Olympics. When Owens finished competing, the African-American son of a sharecropper and the grandson of slaves had single-handedly crushed 
Hitler's myth of Aryan supremacy (Schwartz 2005). And this is what made the story of Jesse Owens and Luz Long so captivating (Goldman 2009). According to the journalist Sver Goldman, at published report in the German newspaper Der Tagesspiegel on July 25, 2016, even after 80 years, Hitler's Games still fascinate a wide audience.

At this point, it's up to us to raise some thoughts: Were the events related the way they really happened? And if, according to other interests, important historical events had been deliberately altered? Was only the Nazi Germany racist? For Altman (2015), many myths are around Owens and the 1936 Games: Hitler would have been so angry with the Owens victory in the long jump which withdrew from the stadium in a hurry? Had Hitler refused to surrender the gold medal after his victory in the $100 \mathrm{~m}$ ? These are important questions that deserve to look further than the simple reproduction of common sense. According to the English writer and journalist George Orwell: "History is written by the victors".

Although many people know better, the myth of Hitler's snub of Jesse Owens at the 1936 Olympics in Berlin is persistent. But that's not where the Olympic myths end. The alleged snub is not even the most important of several Berlin Olympics misconceptions that need correcting (About.com, n.d.). It can be said that no event in the history of modern sport has been more significant in either its impact or implications than the Summer Olympics of 1936 (Miller 1996).

In this way, we find it important to examine the gap between the disparity of shared mythical reports about the XI 1936 Berlin Olympics and the events that actually occurred. The aim of this study is: 1) compile and show as much detail as possible the events that occurred during this Olympiad; highlighting the proof of the long jump, the dispute between Owens and Long; 2) to verify Hitler's reactions toward the African American victories; 3 ) analyze how was the creation of the myth surrounding the athlete Jesse Owens; 4) to present reports on global media coverage, from 1936 to the present day, and analyzing the perpetuating or not of these mythical reports in the current media. To this aim, a wide and diverse research was conducted in several sources: books, papers, documentaries, reports, among others. Without claiming to prove a single fact, it is intended to provide insight to the readers to draw their own conclusions. This research does not consider or defend ideologies of any mentioned countries.

\section{The "battle of colors"}

"The real champion is not the one who comes in first, nor the one who wins the medal, but the one who surpasses its own limits."

In the summer of 1936, the German Luz Long was the European record holder in the jump distance (7.82 m, set at July 11, 1936), was eager to compete against American Jesse Owens, the so called world record holder ( $8.13 \mathrm{~m}$, established on May 25, 1935). The proof of the long jump, held on 4 August, during the Berlin Olympic Games, was his first event against Owens (Easy Web, n.d.). 
In their obsession with racial superiority, the Nazis had dubbed it the "Battle of the Colors". Long's job was to demonstrate the superiority of the Nordic master race (Aryan) to the rest of the world (Wulzinger 2012).

Around 11 a.m. on 4 August (Organization Committee 1937), less than 10 minutes after breaking the Olympic record in the first round of heats for the $200 \mathrm{~m}$, Owens was competing in the qualifying round for the long jump (Murray 2012). During the preliminary round Long broke the Olympic record for this event (International Olympic Committee [IOC] 2011). On the other hand, Owens was almost out of the long jump shortly after qualifying began (Schwartz 2005). He was the world-record holder in this event, but things did not start well. Owens had watched Long take several practice jumps into the sand (Murray 2012). As he was walking along the jumping sector, still wearing a sweater to test the terrain conditions, the red flag was raised, although he had not even jumped (Holmes 1974), and he was immediately told that it had been his first attempt to qualify (Murray 2012). He was stunned when officials counted a practice of a small run down the runway and into the pit as an attempt (Schwartz 2005). In the second attempt, Owens seemed to have a good jump, but the red flag was raised again. He had passed the place limit for the jump (Holmes 1974). It is speculated that probably the judges of organization were pressured by the Nazi regime to annul the heels of Owens and prevent a black race athlete won the race (Martinez 2012). Knowing he needed at least $7.15 \mathrm{~m}$ to qualify for the final, the American sat on the grass discouraged (Schwartz 2005). According to the documentary "Luz Long” produced by Javier Martinez (2012) for the Mexican network Efecto $T V$, the Nazi regime did not expected that Luz Long would do something that would astonish the whole world.

Owens has only one more try, he is impatient. At this moment he felt a hand on his shoulder (Beck 2013). With one jump remaining, Luz Long, a tall, blue-eyed, blond and talented, apparently a model athlete in Nazi era, German long jumper who was his stiffest competition, introduced himself (Höfle 2015; Schwartz 2005). After long presenting, the two chatted awhile. "Jesse Owens, I know what's going on inside you" (Beck 2013). "You should be able to qualify with your eyes closed", Long told Owens (Murray 2012). He knew Owens routinely made distances far greater than this (Jesse Owens Museum [JOM], n.d.). Long said he had been watching two Owens's jumps and made a mark at ground, few centimeters before the take-off board (Broughton 2009; JOM, n.d.). According to Owens, the German then advised him to calculate his last jump a few centimeters (one foot) before the takeoff board for him to jump from a safe place, because he knew that the American would easily reach $7.15 \mathrm{~m}$, and so he would avoid another null trial and disqualification (Altman 2015; Martinez 2012; Murray 2012). After that, Long put as orientation mark your towel next to the take-off board (Beck 2013). Accepting Long`s advice, in his last jump Owens marked 7.64m, ranking easily to the finals (Schwartz 2005; Sports Reference, n.d.). 
According to British journal Manchester Guardian, the home crowd gave "a great roar of admiration" as Owens made it through (Murray 2012). "You see? That's how easy it is", Long reportedly called out to Owens after he had easily qualified for the finals with his last jump. Then, Owens writes, he shook Long's hand and said the only German word he knew: "Danke” [Thank you] (Wulzinger 2012). “All I could offer to Long”, said Owens later, "was my friendship" (Beck 2013).

In 1964, Olympic filmmaker Bud Greenspan made the movie "Jesse Owens Returns To Berlin”. In the film, Owens explains to Luz Long's son, Kai, what happened during the long jump: In the qualifying round, Owens failed on his first two attempts. A third miss, Owens tells Kai, and he wouldn't make it to the final. "And your father came to my assistance", Owens says in the film. "And he helped me measure a foot back of the takeoff board - and then I came down and I hit between these two marks. And therefore I qualified. And that led to the victory in the running broad jump" (Goldman 2009).

In the end, in the late afternoon of August 4, Owens took the lead of the race with a leap of $7.74 \mathrm{~m}$ at the first attempt (Altman 2015). Later, Owens got $7.87 \mathrm{~m}, 7.75 \mathrm{~m}$ and a failure in his $2^{\text {nd }}$, $3^{\text {rd }}$ and $4^{\text {th }}$ jumps, respectively. Long had managed to improve his brands, jumping $7.54 \mathrm{~m}, 7.74 \mathrm{~m}$, $7.84 \mathrm{~m}$ and $7.73 \mathrm{~m}$ in his first 4 jumps, respectively (Sports Reference, n.d.). For Holmes (1974), there were no opponents to Owens until then, when the German Long equaled Owens brand, $7.87 \mathrm{~m}$ on his fifth jump. When Long`s mark was announced, the crowd sighed happily, but this happiness was short lived. Until then, Long was the first in the competition. As he and Owens jumped the same distance, the official criterion for tie is the distance from the second largest jump: Long`s second best jump was 7.84 m; while Owens had jumped 7.75 m (Sports Reference, n.d.).

Long also described what happened after his fifth jump in the main competition, when he achieved his personal best of $7.87 \mathrm{~m}$. The jump brought the crowd to its feet and Long neck-and-neck with Owens. At that moment during the competition of a lifetime, Long felt completely different emotions. "One look at the crowd, which refuses to calm down, and then a look at the Führer's box. What? The entire box is in an uproar? The Führer is clapping enthusiastically", Long wrote. "I stand gratefully beneath my Führer to greet him, and I can hardly believe what I see: He stands up, greets me with his benevolent, fatherly smile, and there is only one wish in his eyes: that I may win" (Wulzinger 2012).

Soon after, in the same round of jumps, Owens jumped $7.94 \mathrm{~m}$ on his fifth jump, and won the gold medal with a final leap of $8.06 \mathrm{~m}$ at the sixth attempt, setting a new Olympic record for the test (Altman 2015; Schwartz 2005 Sports Reference, n.d.). In the final jump, Long was willing to defeat Owens, but failed in his last jump (Holmes 1974).

In this battle of giant jumps, the Olympic record was exceeded five times and matched once (Holmes 1974; Mandel 1987). According to Stadtgeschichtliches Museum Leipzig [Leipzig History 
Museum] ([SML] 2013), the fascinating duel was for the audience a highly emotional experience. Beck (2013) described this event as one of the most memorable competitions of sports history.

Luz Long returned to challenge the Nazi regime, he was the first to congratulate the champion (Altman 2015; Martinez 2012; Schwartz 2005). In a gesture of sportsmanship, respect and tolerance, Luz Long, now silver medalist, congratulated the winner in the sandbox with a hug (SML 2013) and took a victory lap together, arm in arm, before the officials of the Nazi regime (IOC 2011), while the workers stood up to greet them (Altman 2015), then landed with him for photographers, along with the Japanese Naoto Tajima (Martinez 2012), the third in the competition.

Luz Long and Jesse Owens remained true to the Olympic spirit against all odds, in this politically sensitive time (SML 2013). The jump of Owens went so far that he surpassed the ditch of the ideologies. In a world where dark clouds were already gathering, the two athletes gave an example of tolerance and Fair Play (Beck 2013). It's a real Olympic moment that transcending all racial barriers of Nazism (Höfle 2015). It was a noble gesture by German track and field athlete. But, for the Nazis it was an outrage. After the episode of Long hugging Owens, Rudolf Hess later reprimanded him for it. According to Long's mother, Hitler's deputy had ordered her son to "never embrace a negro again" (Wulzinger 2012).

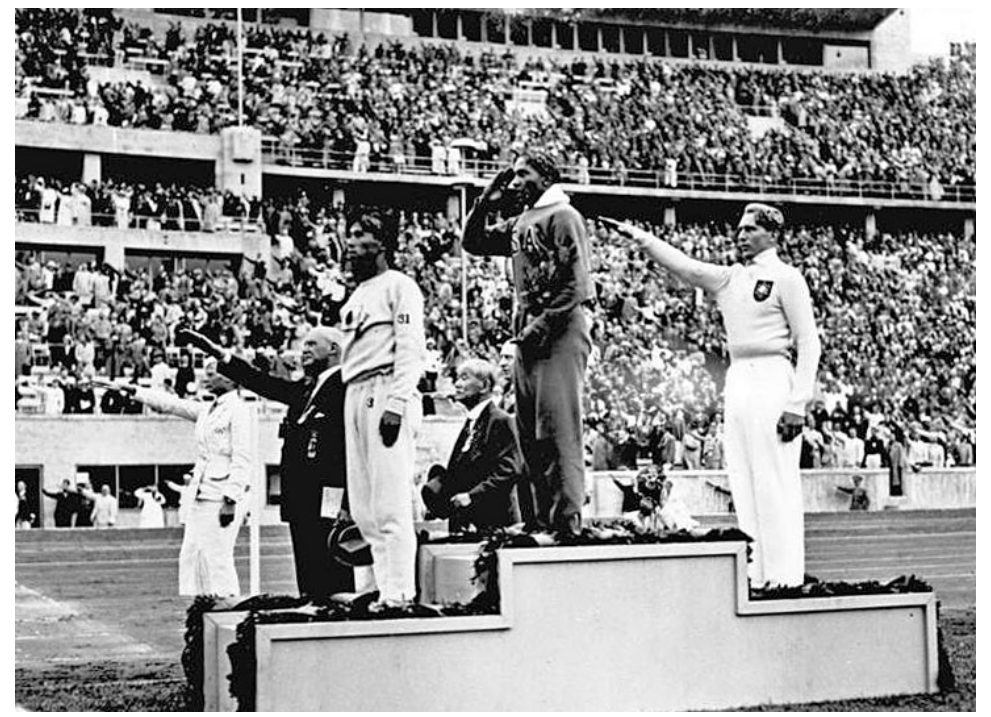

Figure 1

Jesse Owens (center) during the gold medal award ceremony for the long jump, amidst a sea of Nazi salutes in Berlin (Bundesarchiv).

Hitler called Long particularly and greeted, as the foreign newspapers reported, cheerful, to have performed the feat to come second after a black stranger (Holmes 1974). So reported The New York Times of August 10, 1936: "So delighted was Chancellor Hitler by the gallant fight that Long had made that he congratulated him privately just before he himself left the stadium. In fact, his eagerness to receive the youthful German was so great that the Fuehrer condescended to wait until 
his emissaries had pried Long loose from Owens, with whom he was affectionately walking along the track arm and arm".

According to Michael Wurzinger (2012), in an article published in the German magazine Der Spiegel, a week after Long`s jump duel, however, Long gave his own version of the event in a story entitled "Mein Kampf mit Owens" [My Battle with Owens] published at August 11, 1936 in the Neue Leipziger Zeitung, his hometown newspaper, Leipzig. He wrote: “I couldn't help myself. I ran up to him, and I was the first to embrace and congratulate him. He responded by saying: You forced me to give my best!"

According to the documentary "Luz Long, ein Held in der Nazi-Zeit" [Luz Long, a hero in Nazi era], written by Maren Höfle (2015), the German newspaper Neuen Leipziger Zeitung of August 11, 1936 stamped the following sentence: "Der Kampf der Farben ist beendet. Schwarz war der Beste, einwandfrei der Beste, mit 19 Zentimeter vor Weiß" [The battle of colors is completed. The black was the best, properly the best, with $19 \mathrm{~cm}$ in front of the blank]. According to the report of Oskar Beck, published in the German newspaper Die Welt of May 1, 2013, this phrase was so extraordinary, bold and dangerous, which crowned the memorial exhibition of the $100^{\text {th }}$ anniversary of the birth of Luz Long, the famous son Leipzig. He was the loser in the battle of colors. He was white.

\section{"New" moments of an old story}

"The real voyage of discovery consists not in seeking new landscapes, but in having new eyes." (Marcel Proust)

The "official story" says that a black man entered Hitler's Coliseum and destroyed the theory of Aryan physical supremacy by winning four gold medals in track and field. The Führer, according to legend, was so horrified by Owens's triumph, he stormed from the Olympic stadium rather than shaking his hand, as he had with every other medalist (Broughton 2009). This famous passage would have occurred in the competition test of the distance jumping, as the main competitor for the gold medal was the German athlete Luz Long (Salun 2012).

However, Rick Shenkman (2013) at book "Legends, Lies, and cherished Myths of American History" counterclaims that the myth concerning Owens and Hitler was completely unfounded. Despite there being a lovely ring of poetic justice about it, the myth isn't true (Belam 2008). According to William Baker, professor and Owen`s biographer the newspapers made the whole story (Shenkman 2013). This legend, which has lasted nearly 80 years, was created by American sportswriters still during the 1936 Olympic Games. However, the episode of the departure of Hitler's Olympic Stadium did not occur after Owens win the 100m (day August 3) or the jump distance (August 4). This episode actually took place on August 2 (first day of competitions in athletics) during the finals of the high jump. 
According to Holmes (1974), there are many versions of this incident, but the most likely came from K. C. Duncan, secretary of the British Olympic Association. After having greeted the German Hans Wolke (shot put champion) and the Finnish Ilmari Salminen (10.000 m champion) and 2 German athletes, Hitler was warned by IOC members, as guest of honor, not to greet publicly winners of any competition and it happened just shortly before Cornelius Johnson`s victory (AfricanAmerican black, high jump champion). According to the IOC, the rush and confusion that this entailed, with hundreds of photographers, cameramen, reporters, public security seeking to approach Hitler was delaying the normal course of the games. Hitler then decided not to go down over the tribune of honor. After the first day, he decided to acknowledge none. Jesse Owens had his victories on the second day, when Hitler was no longer in attendance (About.com, n.d.).

The official explanation at the time was that it was threatening to rain and therefore the Führer withdrew. But it is clear that the incident was tailor-made for those who disapproved of the racial policy of Hitler. Herb Flemming, a black jazz musician on the US team as an interpreter, illustrates how badly it was because of the fact, telling that when Hitler left the stadium, the crowd, predominantly German, murmured as if embarrassed by what happened. And so the first day of athletics competition ended the story of Hitler's withdrawal from the stadium echoing worldwide (Holmes 1974).

Newspapers in the United States published news stating that Hitler refused to congratulate the national athletes. In a report written by Arthur Daley, for The New York Times of August 3, 1936, was that stamping "Hitler greets all medalists except Americans" (figure 2, 3).

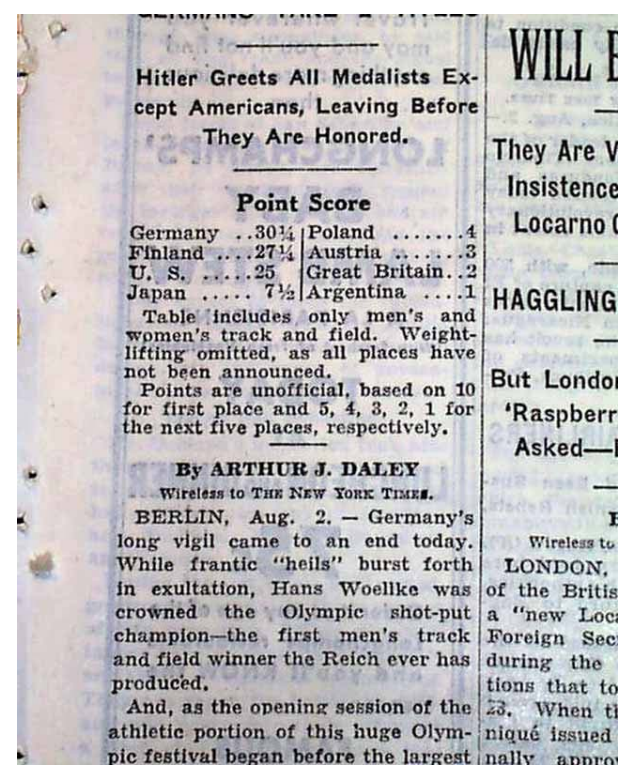

Figure 2

Report stating that Hitler refused to congratulate American athletes (The New York Times)

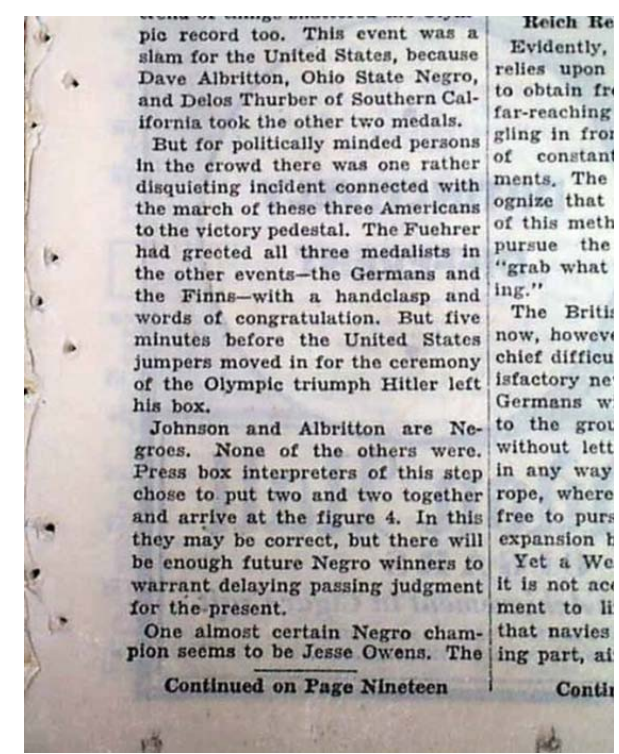

Figure 3

Report on Hitler's output of the Olympic Stadium (The New York Times) 
Also according to the report in The New York Times (Figure 3), explaining Hitler's output of the Olympic Stadium: "But for politically minded persons in the crowd there was one rather disquieting incident connected with the march of these three Americans to the victory pedestal. The Führer had greeted all three medalists in the other events - the Germans and the Finns - with a handclasp and words of congratulations. But five minutes before the United States jumpers moved in for the ceremony of the Olympic triumph Hitler left his box".

Although the original fact that Hitler did not greet American athletes, it had been in relation to Cornelius Johnson and Dave Albrigtton (champion and vice champion of high jump), Jesse Owens ran the second round of the playoffs the $100 \mathrm{~m}$ after the end of the high jump. Although initially denying having been snubbed, Owens reportedly grew tired of the hassle and began to affirm Hitler's racist atrocity. Facts were mingled and Owens, the most well known of the three, emerged as the primary icon of the insult. He came to represent, for the American culture, everything that was wrong with the concept of Aryanism. On the other hand, the German media seized the opportunity to declare the collapse of the white American athletes.

In the article "Evitato Roosevelt, non da Hitler. Un film rivela la verità di Owens" [Shunned by Roosevelt, not Hitler. A film reveals the truth of Owens], the Italian newspaper Corriere della Sera, Gaia Piccardi (2016) writes that Marlene Owens, daughter of Jesse said to the writers of the film that the fact that his father was despised is not true: "Actually, my father never felt snubbed by Hitler", said Marlene. According to History Channel (n.d.), the press reported that the German leader gave the American sprinter a "friendly little Nazi salute" and Owens said that the two exchanged congratulatory waves. In the words of Owens himself: "After I left the podium, I passed the grandstand to return to the locker room. The Chancellor looked at me. He stood up and greeted me with a wave of his hand. I did the same, answering the greeting. Journalists and writers showed bad taste reporting hostility that, in fact, there never was", Owens wrote in his autobiography (Owens 1970).

The American newspaper The Bethlehem Globe-Times published report, on August 3, 1936, stating that Hitler welcomed Owens its platform: "Owens was brought the box bellow that of the chancellor. The latter raised his hand in the Nazi salute and Owens responded with a bow, then descended to the track with his spiked shoes in this hand. It was said Owens may be officially greeted by the Führer when medals are awarded for this event".

When Owens won the $200 \mathrm{~m}$ race in August 5, 1936, winning his third gold medal, he aimed his eyes to the IOC and not to the Hitler`s tribune, because Hitler was absent on the day. Jesse Owens was cheered by thousands of fans from different nations that day. The crowd in 
Berlin was captivated by him; his name was acclaimed so announced before the race and thus ending a dispute, dressing the way, he was continually stopped by the spectators who wanted to photograph him (Altman 2015).

Crowds of 110.000 cheered him in Berlin's glittering Olympic Stadium and his autograph or picture was sought as he walked the streets (Schwartz 2005). Owens spent the Games time being surrounded by German fans on the streets. He stayed in the same place that white athletes, a privilege that had been denied in their own country (Altman 2015). Owens was a true celebrity in Berlin, mobbed by autograph seekers to the point that he complained about all the attention. He later claimed that his reception in Berlin was greater than any other he had ever experienced (About.com, n.d.). Owens had been prepared for a hostile reception; a coach had warned in advance not to be disturbed by anything that might happen in the stands. "Ignore the insults", it was said Owens, "and you'll be fine". Owens later recalled that he had obtained the biggest ovations of his career in Berlin (Shenkman 2013).

Some authors have already agreed that many facts of the 1936 Olympics did not happen exactly the way they are historically numbered. According to new statements, although Hitler had left the stadium, it was not before greeting Owens (Hall 2009). According Broughton (2009), a moment of seeming moral clarity, of good versus evil, is now starting to look more complex. A German sports reporter, Siegfried Mischner, has claimed Owens carried a photograph of himself shaking hands with Hitler and called it "one of my most beautiful moments".

According to Hall (2009), Mischner said: "It was taken behind the honor stand and so not captured by the world's press. But I saw it, I saw him shaking Hitler's hand”. Mischner says he and several other reporters saw the handshake behind the stands at the Olympic stadium but never mentioned it. Owens and other eyewitnesses always maintained that the story of Hitler's snub was exaggerated (Broughton 2009).

According to the report in the Daily Mail newspaper, written by Allan Hall (2009), Owens, who felt the newspapers of the day reported "unfairly" on Hitler's attitude towards him, tried to get Mischner and his journalist colleagues to change the accepted version of history in the 1960s. The picture just would not have been published because the predominating opinion in post-war Germany was that Hitler had ignored Owens. According to Mischner himself: "We therefore decided not to report on the photo. The consensus was that Hitler had to continue to be painted in a bad light in relation to Owens" (Hall 2009; Mais Historia 2015), and the false propaganda ally want to devote Owens, who won four gold medals and won the German Luz Long. 
In his master's thesis, Casey Nash (2012) states that, to the public, after World War II Owens became a sport icon and Hitler became the manifestation of evil. The relationship continued to evolve through the years until the details were no longer relevant. Owens' Olympic feats ceased to be mentioned without reference to Hitler's Aryan ideals and were celebrated by sportswriters as though Owens had competed against Hitler himself.

\section{Owens versus North American hypocrisy}

"The most evil of hypocrisy is simply not advise what you just do not do. But believe you're still really happy that!" (Augusto Branco)

Always when it is referred to the story of Jesse Owens and the 1936 Olympics, it is told almost exclusively about the victory of a black against the racist theory of Hitler and Nazism, of good against evil. However, it is rarely told anything about the racist policy in which the United States lived in the same time. The repeated presence of African-American athletes on the medals podium called attention to the racial policies and practices not only in the country hosting the Olympics but also in their own homeland, where segregation was the ruling custom, South and North, when it was not also the law (Miller 1996). For many African Americans athletes this was pure hypocrisy, they were concerned more about segregation at home than in Germany (Krüger 2008). It was Owens' treatment back home in the USA that tends to get glossed over in any re-telling of the tale (Belam 2008). The continuing social and economic discrimination that black medalists faced upon returning home underscored the irony of his victories in racist Germany. The American journal The Chicago Defender talked about the hypocrisy of amateur athletic leaders who criticized the policies of the Nazis while remaining silent about racial persecution in the United States (Miller 1996). Thus, it seems a huge contradiction to the United States, until today, criticizing the Nazi racial policy, while their own country also had a sectarian policy.

Just as sure as Owens knew fascism was evil, he also knew his country had ways to go too in improving life for African-Americans (Schwartz 2005). Owens (1970) said in his autobiography: "When I came back to my native country, after all the stories about Hitler, I couldn't ride in the front of the bus. I had to go to the back door. I couldn't live where I wanted. I wasn't invited to shake hands with Hitler, but I wasn't invited to the White House to shake hands with the President, either". The greatest achievement of Owens did not oppose the Hitler regime, but shake the racist notion of the American nation in the 20th century, as he made clear in his autobiography. Owens said: "It was not Hitler who ignored me, who did it was Franklin Delano Roosevelt. The president did not even send me a telegram” (Duarte 2012; Shaap 2007), 
congratulating him for his Olympic achievements. In his home country, he was discriminated against for being black, as in the United States a racial segregation policy was still in force (Altman 2015), based on the traditional ideology (white, male chauvinist and Protestant).

In early 20th century United States, the backdrop against African American sprinters competed was kind of a divided country. The "Jim Crow laws" enacted between 1876 and 1965 mandated the segregation of African Americans from the white population across public institutions, services and employment, predominantly in the Southern states, but across the North also. Black sportspeople were banned from competing in the major leagues, and all blacks were prohibited from entering restaurants, bars, clubs, hotels and other facilities (Arogundade 2012). In America, the issue of race had historically been a tragic one. White supremacy in America was only a variation of those beliefs held around the world, which manifested itself in the form of bigotry and blood spill (Nash 2012).

According to Broughton (2009), to celebrate the Olympic victories, Owens was organized tickertape parade in New York. But when he arrived at the Waldorf Astoria hotel for a reception in his honor, he was instructed to take the service lift rather than the normal guest lift, which was reserved for whites. According to the cultural director of the Brazilian Olympic Committee, Christiane Paquelet responsible for the interactive exhibition "Jogos Olímpicos: Esporte, Cultura e Arte" [Olympic Games: Sport, Culture and Art] due to this existing racism in the United States later Owens was on an event at the White House, while all their white companions entered the front door, Owens was forced into the back (Mais Historia 2015). Owens experienced as a fourfold Olympic champion the same discrimination as the rest of the black population of the USA (Kluge 2014). Because of racial discrimination in his native land, Jesse Owens was not able to enjoy anything close to the huge financial benefits that African American athletes can expect today (About.com, n.d.).

According to a report written by journalist Philip Broughton, entitled "Forget Hitler America snubbed black Olympian Jesse Owens", published in the British newspaper Daily Mail, at August 11, 2009, Owens always resisted his role as a political symbol. Having grown up in the segregated American South, the grandson of slaves, he was impatient with American claims of moral superiority over the Nazis. Due to the prevailing racism in American society of the time, not quality job, the Olympic champion and national hero got. "When I returned from the 1936 Summer Olympics, with my four medals, it became increasingly clear that everyone would continue to give me pats on the back, shake my hand or invite me to their suite .But no one was going to offer me a job" (Gentry 1990). 
Six months after the Olympics, Owens became professional, ending his athletic career under the rules then in force, the Amateur Athletic Union of the United States. With the money earned after the Gameshe bought a house for his parents and a car for his coach, but soon he got into financial difficulties (Altman 2015). Then he worked at an amusement park, because he did not find better jobs. To support the family, he made public exhibitions, betting racing with motorcycles, dogs and horses (Duarte 2012). "The People said it was degrading for an Olympic champion to run against a horse, but what was I supposed to do?" Owens said. "But what could I do? I had four gold medals, but you can't eat four gold medals" (Altman 2015; Broughton 2009; Schwartz 2005). In reality, his life and the way his myth has been exploited is not nearly so straightforward (Broughton 2009).

\section{The Olympics of 1936 and the result of Nazi Germany}

"The great achievement is the result of small victories that go unnoticed." (Paulo Coelho)

According to the Official Report of the Games, the Olympic Games were a sporting event of gigantic proportions. These games represented all the ability of the German organization, technical skill and craftsmanship combined with the forecast accuracy and were able to perform during long years of hard work (Organisations committee 1937). The 1936 Olympics was a milestone in the history of the event. The Nazi state machine hosted the best Olympic Games until then (Sigoli \& De Rose Jr. 2004).

In total, 51 countries around the world competed in the Berlin Games, higher number than in any previous Olympics (United States Holocaust Memorial Museum [USHMM] n.d.). Media coverage of the Games was the most intense so far. For the first time more than 41 countries were able to follow the games on the radio (Nestler, n.d.), 20 broadcast vans were made available to foreign media (Trueman 2015). More than 300 radio stations broadcast the Games in more than 25 languages (Mostaro 2012). More than 300 million people on all continents followed the Nazi Olympics over the radio, by far the largest radio audience of any event up to that date (Krüger 2008). These were the first games televised, even if only in Berlin (Mostaro 2012). The Olympics had great popular success, proven by over 3 million viewers who watched the games from the stands (Morasha 2004). 150.000 people watched the Games on 28 transmission rooms scattered around the capital. Movie theaters functioned as television today. It was the great audiovisual vehicle in the 30 (Ferreira 2002).

The grandeur of the event and some events that occur in the current Olympics had their genesis in this Olympics: a runner arrived at the scene carrying a torch that had been carried by relay from the site of the ancient Games in Olympia, Greece (USHMM, n.d.); a giant bell with 
the inscription "Ich rufe die Jugend der Welt" [I call the youth of the world] celebrated the arrival of the torch in the Olympic city (Nestler, s.d.); the "medals table" was published for the first time in this dispute to demonstrate Germany's supremacy, if the Germans wanted to demonstrate to the world that had been reborn through the games, they had to demonstrate with facts that were the winners of the Olympic Games; it was made an Olympic anthem by Richard Strauss, especially for games (Mostaro 2012); hundreds of athletes wearing sports attire gala marched through the stadium, one team at a time, by countries in alphabetical order. Inaugurating other new Olympic ritual (USHMM, n.d.), and these delegations, for the most part, were the Hitler salute when passing the grand stand where the dictator was located (Mostaro 2012); it was also made a film about the event, the film "Olympia" filmmaker Leni Riefenstahl, released on April 20, 1938 (49 ${ }^{\text {th }}$ anniversary of Hitler).

This event was organized in every detail in order to be a revival landmark of the country before the world (Salun 2012). A secret memorandum transmitted on July 18, 1936 to all security forces warned: "The great developing and without incidents of the 1936 Berlin Olympic Games, is of utmost importance for the image of the new Germany in the eyes of our foreign guests" (UOL 2008). Through the Games, Germany proved to be reborn to other countries and the great works showed how the country had been redone in such a short time (Mostaro 2012). According to Sigoli and De Rose Jr. (2004), Hitler was able to show the world the totalitarian power of German Nazism and impressed everyone with social organization promoted by the same, but did not succeed in demonstrating the supposed racial supremacy of the Aryan Germans, who were defeated by black, Asian and Jewish athletes.

Here we can set another reflection: Hitler was defeated? It is often stated that Jesse Owens' four gold medals humiliated Hitler by proving to the world that Nazi claims of Aryan superiority were a lie. But Hitler and the Nazis were far from unhappy with the Olympic results. Not only did Germany win far more medals than any other country at the 1936 Olympics, but the Nazis had pulled off the huge public relations coup that Olympic opponents had predicted, casting Germany and the Nazis, falsely, in a positive light. In the long run, Owens' victories turned out to be only a minor embarrassment for Nazi Germany (About.com, n.d.).

Germany was the champion of the XI Olympiad, winning 89 medals in total, $59 \%$ of medals more than the second place, with 33 gold medals, $37.5 \%$ more, also the second place, the United States. The athlete with the most medals at the Olympics was the German Konrad Frey (artistic gymnastics) with 6 medals in total (3 gold, 1 silver and 2 bronze).

As stated by Huizinga (2001 as cited in Mostaro 2012), in every game it is very important that the player can boast to others of their successes. Germany boasted through the 
"medals table" and reinforced the Nazi propaganda of a strong state and superior to the world. The Games were a "war" that the Germans won and inflated their self-esteem to the real war that was to come.

German athletes won the most medals and the hospitality and the German organization received praise from visitors. The treatment given to the delegations and journalists by the Nazis was well received by the international community (Mostaro 2012). Most newspapers concluded, as did Frederick Birchall in the American newspaper The New York Times, that the games put Germans "back to the community of nations" and even made them "more human again" (USHMM, n.d.). German media trumpeted the victories won by their athletes, highlighting the revival of the nation led by Hitler. Germany was the country that received the largest number of medals, breaking the hegemony of the United States. Among the papers of the two countries a small battle over this sporting event was fought because the media's role was to serve as a political propaganda tool, both in dictatorships as in liberal democracies (Salun 2012). In case of dispute the 1936 Olympic Games, the result was a mixture of American and Nazi propaganda. Both the American and the German media attempted to put forth their own interpretations. The Germans claimed that the "Black auxiliaries" 24 presence at the Games showed the decline of white American athletes. The American media turned Owens into a national hero.

After the 1929 world crisis of capitalism, idolatry and the creation of myths, including sports, can be easily understood, because, according to Salun (2012), the 1930s was a golden era in the construction of myths in sports, film and music. Thus, after the victories in the 1936 Olympics, this was one of the reasons for creating and spreading the myth around Owens.

\section{The Pierre de Coubertin medal}

"Winning or losing is part of the sport, the way you win or lose is what makes you victorious or not." (Caio Ribeiro)

The Coubertin Medal Pierre is a sports-humanitarian award given by the International Olympic Committee athletes and people involved with sports that demonstrate a high degree of sportsmanship and the Olympic spirit during the dispute of the Games (Scrivener 2008). Unlike gold medals, silver and bronze, that medal - that is all made of gold - has no relation to the technical performance competitive, but with its moral and ethical qualities and demonstration of pure sportsmanship in difficult or unusual situations taken place during disputes. For this reason, the medal is considered by the IOC as its highest honor (International Olympic 
Committee, n.d.), have been granted to date only a few personalities and some athletes who participated in the Olympics.

According to Martinez (2012), in the history of the Olympic Games there are only stars that shone for his great quality as athletes, but also for his great human quality and what this meant. Also according to Martinez (2012), Luz Long won the silver medal in the long jump. However, it is best known for having advised his then rival, and later friend, Jesse Owens would end winning the gold medal with the help of Long. This earned him one of the greatest recognitions of world Olympism. Its sporting behavior is considered exemplary for the ideals of the Olympic Movement (Kluge 2014).

According to Scott Murray, in his article published in the British newspaper The Guardian on February 10, 2012, celebrating the most honorable moments in sports, the story of Luz Long and his act of selflessness is perhaps the most famous in sporting history. It was a moment that would go down in history, a story of human courage, which defied the Nazi regime and earned Long a place in history as an athlete of great valour (World Olympians Association 2015).

Due to the Olympic spirit shown by Luz Long during the race the long jump at the 1936 Olympics, in 1964 the International Olympic Committee gave Long the Pierre de Coubertin Medal. Long was posthumously awarded the medal for his sportsmanship since died in 1943 in front of Italian battle, fighting with the troops of the Wehrmacht during World War II. The German documentary titled "Luz Long, ein Held in der Nazi-Zeit" "shows the striking portrait of a man who was very fair, decent. Luz Long, a silent hero who is admired throughout the world until today for their bravery". In honor of the Aryan athlete who faced his own regime and gave an example of what is the true Olympic spirit, roads and streets bear his name near the stadium in his hometown, Leipzig, and other nearby Olympic Stadium in Munich (Martinez 2012). His silver medal, photographs and documents were donated to the Sportsmuseum Leipzig [Leipzig Sport Museum].

Long and Owens kept in touch by letters after Berlin. Long wrote a last letter to Owens in the end in 1942, shortly after the United States declared war on Germany: "My heart is telling me that this is perhaps the last letter of my life. If so, I ask you something. When the war is over, please go to Germany, find my son and tell him about his father. Tell him about the times in which the war is not in the parts and tell him that things can be different from men in this world. His brother, Luz" (Duhaime 2009).

Once finalized the war, Owens traveled to Germany to meet the family of his eternal friend. Before them, Jesse Owens said: "A lot of courage was necessary for him to have been 
my friend in front of Hitler... You can melt all the medals and cups I have, and that would not be worth anything compared to 24 karat friendship I felt for Luz Long at that moment" (IOC 2011; Martinez 2012). Owens had his own memories of Berlin which differed starkly from the propaganda version. He later said that his greatest memory of the Games was not the races, the medal ceremonies or the politics. It was of his German rival in the long jump, Luz Long (Broughton 2009).

\section{Final reflections}

Trying to show an accurate version of events, as we analyze in the text, not all events occurring during the 1936 Berlin Olympics happened exactly the same way as they are usually counted historically. Some conclusions about the 1936 Olympic Games are extremely obvious: 1) Hitler, as head of the Games organizing country government obviously wanted that Germany was the champion of the Games; 2) no doubt, Hitler was a racist, then do not like to see his athletes losing to black athletes; 3) Owens was an excellent athlete with exceptional brands; iv) certainly, the myth around Owens grew because of the racism of Nazi ideology than by facts really occurred between Hitler and the American athlete. It is part of the American culture the pursuit of its hegemony and the creation of myths, in any area. We can easily realize this fact by several American films, through the stories of super heroes, etc. Of course with the history of Owens, though winning and true in many ways, it would be no different. His myth has been working to be bigger, more beautiful and more "romantic" than it truly was. So it was certainly overvalued.

From an American point of view, the myth does three things: a) it simplifies the overall reality of events, while preserving the desired message; b) in addition, it simultaneously glorifies American heritage and defies Nazi ideals; c) heritage is the highly disputed branch of History which lends itself to the self-aggrandizement of a culture regarding its own past. Similar, you will note, to the way that myth is presented in popular memory.

According to Wilson (2007), Owens wrote three "autobiographical" books co-written by Paul Neimark. Owens' himself had mentioned that a number of incidents recounted in the books were exaggerations and fabrications which helped build his reputation. Over the years most historians have questioned the value of these books as records of fact. Nowadays, part of the media also questions (and even denies) the veracity of some facts related to Owens and the 1936 Olympics. Thus, adding to the excellent athletic performance of Owens, the fact of being American, and these events have just occurred in the 1936 Olympics, played in full Nazi 
Germany, we have the perfect setting for the creation of myths and symbols. As previously mentioned, this may not be the greatest misconceptions related to the 1936 Olympics.

By demonstrating a true Olympic spirit, which goes far beyond a simple athletic brand, a medal or a record; for his courage to "face" the Nazi regime; and his sense of friendship; perhaps the greatest myth of the 1936 Olympic Games was the German athlete Luz Long. Undoubtedly, in this Olympic spirit, Luz Long can also be considered one of the most important athletes in Olympic history. However, being German and have played the Olympics under the auspices of the Nazis swastika and Hitler's eyes, and as a way of devaluing the Germans made in this Olympics and everything that relates to Nazism, its history has never had as much impact as the African-American athlete Jesse Owens.

\section{References}

1. COMITÊ OLÍMPICO BRASILEIRO, 2006. Informações sobre o uso de medicamentos no esporte. Rio de Janeiro: Comitê Olímpico Brasileiro.

2. HOLMES, J., 1974. Berlim 1936: glória do Reich de Hitler. Rio de Janeiro: Editora Renes.

3. FERREIRA, F., 2002. Olympia: o triunfo do corpo. Rio de Janeiro, UFJF.

4. GENTRY, T., 1990. Owens: Champion athlete. New York: Chelsea House Publishers.

5. DUARTE, M., 2012. O guia dos curiosos: Jogos Olímpicos. São Paulo: Panda Books.

6. INTERNATIONAL OLYMPIC COMMITTEE, 2011. Hope: when the sport can change the world. Lausanne: CIO.

7. KLUGE, V., 2014. 100 Jahre Jesse Owens und Luz Long - siegt die Legende gegen die Wahrheit? [Abstract]. Stadion: internationale Zeitschrift für Geschichte des Sports, 38, pp. 105-124.

8. KRÜGER, A., 2008. Olympic Games of 1936. In: MOORE, J. H. (Ed.). Encyclopedia of Race and Racism (2 $2^{\text {nd }}$ ed., pp 381-384). Detroit: Macmillan. pp. 381-384.

9. LEITE, W., 2015. The relationship Education $x$ Sport in Brazil: two sides of the same coin. International Journal of Education and Information Technology, 1(3), pp. 111-116.

10. MAIA, M., 2010. Dimensões sociais do esporte: perspectivas trabalhadas nas escolas da cidade de Pau dos Ferros, RN. Revista EFDeportes.com, n. 144.

11. MANDELL, R., 1987. The Nazi Olympics. Urbana, Chicago: University of Illinois Press.

12. MILLER, P., 1996. The Nazi Olympics: Berlin 1936. Olympika: The International Journal of Olympic Studies, 5, pp. 127-140. 
13. MOSTARO, F., 2012. Jogos Olímpicos de Berlim 1936: o uso do esporte para fins nada esportivos. Logos: Comunicação \& Entretenimento, 19(1), pp. 95-108.

14. NASH, C., 2012. The Olympic glory of Jesse Owens: A contribution to civil rights and society. Johnson City. East Tennessee State University. Master Thesis. Faculty of the Department of History.

15. ORGANISATIONSKOMITEE FÜR DIE XI. OLYMPIADE BERLIN 1936 E. V., 1937. Official Report. Berlin: Wilhelm Limpert.

16. OWENS, J., 1970. The Jesse Owens History. New York: Putnam.

17. SALUN, A., 2012. Esportes e propaganda política na década de 1930. Contemporâneos: Revista de Arte e Humanidades, 10, pp. 11-15.

18. SCHAAP, J., 2007. Triumph: the untold history of Jesse Owens and Hitler's Olympics. Houghton Mifflin: Boston, New York.

19. SHENKMAN, R., 2013. Legends, Lies, and cherished Myths of American History. New York: Harper Collins.

20. SIGOLI, M., DE ROSE JR., D., 2004. A história do uso político do esporte. Revista Brasileira de Ciência e Movimento, 12(2), pp. 111-119.

21. WILSON, R., 2007. Book reviews [Review of the book Triumph: the untold story of Jesse Owens and Hitler's Olympics]. Journal of Olympic History, 15(1), p. 48.

\section{Electronic sources}

22. ABOUT.COM, n.d. Who really snubbed 1936 Olympic champion Jesse Owens? [cit. 201612-10]. Accessible from: http://german.about.com/library/blgermyth10.htm

23. ALTMAN, M., 2015. Berlim, 1936: Em plena Alemanha nazista, Jesse Owens confronta mito da supremacia ariana e conquista quatro medalhas de ouro. [cit. 2016-12-07]. Accessible

from:

http://operamundi.uol.com.br/conteudo/samuel/39921/berlim+1936+em+plena + alemanha + nazista + jesse + owens + confronta + mito + da + supremacia + ariana + e + conquista + quatro + med alhas + de + ouro.shtml

24. AROGUNDADE, B., 2012. The 1936 Olympics: the man who beat Jesse Owens. [cit. 201612-17]. Accessible from: http://www.huffingtonpost.com/ben-arogundade/1936-olympicsjesse-owens b 1700705.html

25. BECK, O., 2013. Der weite Sprung. April 2013. [cit. 2017-02-02]. Accessible from: https://www.welt.de/print/welt_kompakt/print_sport/article115551848/Der-weiteSprung.html 
26. BELAM, M., 2008. A brief history of Olympic dissent: Berlin 1936. [cit. 2016-12-26]. Accessible from: http://www.currybet.net/cbet blog/2008/08/a-brief-history-of-olympicdis-3.php

27. BROUGHTON, P., 2009. Forget Hitler - America snubbed black Olympian Jesse Owens. August 2011. [cit. 2017-06-04]. Accessible from: http://www.dailymail.co.uk/news/article$\underline{\text { 1205901/Forget-Hitler--America-snubbed-black-Olympian-Jesse-Owens.html }}$

28. DALEY, A., 1936. 110,000 see Owens set World Record at Olympic Games. August 1936. [cit. 2017-01-10]. Accessible from: https://partners.nytimes.com/library/national/race/080336race-ra.html

29. DUHAIME, L., 2009. Luz Long: 1913-1943. [cit 2016-12-11]. Accessible from: http:/www.duhaime.org/LawFun/LawArticle-669/Luz-Long-1913-1943.aspx

30. EASYWEB., n.d. European Records Progression (Men). [cit. 2016-12-11]. Accessible from: http://easyweb.easynet.co.uk/ rsparks/eurrec-m.htm

31. GOLDMAN, S., 2016. Olympia 1936 - Wahrheit und Dichtung. July 2016. [cit. 2017-0121]. Accessible from: http://www.tagesspiegel.de/sport/luz-long-und-jesse-owensolympia-1936-wahrheit-und-dichtung/13918232.html

32. GOLDMAN, T., 2009. Was Jesse Owens' 1936 Long-Jump Story A Myth? [cit. 2016-1208]. Accessible from: http://www.npr.org/templates/story/story.php?storyld=111878822

33. HALL, A., 2009. Did Hitler shake hands with black 1936 Olympic hero Jesse Owens? August 2009. [cit. 2017-02-01]. Accessible from: http://www.dailymail.co.uk/news/article$\underline{\text { 1205572/Hitler-shook-hands-black-1936-Olympic-hero-Jesse-Owens.html }}$

34. HISTORY CHANNEL, n.d. 10 things you may not know about Jesse Owens. [cit. 2016-1218]. Accessible from: http://www.history.com/news/10-things-you-may-not-know-aboutjesse-owens

35. HÖFLE, M., 2015. Luz Long, ein Held in der Nazi-Zeit [Video]. [cit. 2017-02-03]. Accessible from: http:/www.ndr.de/fernsehen/sendungen/sportclub/Leichtathletik-WMPeking,sendung404972.html [in German]

36. INTERNATIONAL OLYMPIC COMMITTEE, n.d. Jesse Owens. [cit. 2016-12-02]. Accessible from: http://www.olympic.org/museum

37. JESSE OWENS MUSEUM, n.d.. Long jump pit. [cit. 2016-12-16]. Accessible from: http://jesseowensmemorialpark.com/wordpress1/long-jump-pit

38. MAIS HISTÓRIA, 2015. Jesse Owens: o homem que desafiou Hitler. [cit. 2016-12-20]. Accessible from: http://maishistoria.com.br/jesse-owens-desafiou-hitler/ 
39. MARTINEZ, J., 2012. Luz Long [Video]. [cit. 2017-01-17]. Accessible from: https://www.youtube.com/watch?v=Cz4j8GzCS 4 [in Spanish]

40. MORASHÁ, 2004. Berlim 1936 - As Olimpíadas Nazistas. [cit. 2016-12-13]. Accessible from: $\quad$ http://www.morasha.com.br/antissemitismo/berlim-1936-as-olimpiadasnazistas.html\#q=1936

41. MUNRRAY, S., 2012. The Joy of Six: Sportsmanship. February 2012. [cit. 2017-01-07]. Accessible from: http://www.theguardian.com/sport/blog/2012/feb/10/joy-of-sixsportsmanship

42. NESTLER, S., n.d. 1936: abertura dos Jogos Olímpicos de Berlim. [cit. 2016-12-07]. Accessible from: http://www.dw.com/pt/1936-abertura-dos-jogos-ol\%C3\%ADmpicos-deberlim/a-601469

43. PICCARDI, G., 2016. Evitato da Roosevelt, non da Hitler. Un film rivela la verità di Owens. January 2016. [cit. 2017-03-19]. Accessible from: http://www.corriere.it/sport/16_gennaio_02/evitato-roosevelt-non-hitler-film-rivela-veritaowens-464f958e-b121-11e5-b083-4e1e773a98ad.shtml\#

44. SCRIVENER, P., 2008. Olympic countdown - 64 - Olympic spirit. [cit. 2016-12-02]. Accessible from: http://www.bbc.co.uk/blogs/olympics/2008/06/olympic_countdown_64_olympic_s.html

45. SPORTS REFERENCE, n.d. Luz Long. [cit. 2016-12-04]. Accessible from: http://www.sports-reference.com/olympics/athletes/lo/luz-long-1.html

46. TRUEMAN, C., 2015. The 1936 Berlin Olympics. [cit. 2016-12-11]. Accessible from: http://www.historylearningsite.co.uk/nazi-germany/the-1936-berlin-olympics/

47. UNITED STATES HOLOCAUST MEMORIAL MUSEUM, n.d. As Olimpiadas nazistas - Berlim, 1936. [cit. 2016-11-27]. Accessible from: http://www.ushmm.org/wlc/ptbr/article.php?ModuleId=10005680

48. UOL, 2008. 1936 - Olimpíadas de Berlim. Accessible from: http://olimpiadas.uol.com.br/2008/historia/1936/historia.jhtm

49. WORLD OLYMPIANS ASSOCIATION, 2015. Story of Olympic Solidarity Inspires Book. [cit. 2016-11-09]. Accessible from: http://olympians.org/news/397/story-of-olympicsolidarity-inspires-book/

50. WULZINGER, M., 2012. Kampf der Farben. January 2012. [cit. 2017-03-26]. Accessible from: http://magazin.spiegel.de/EpubDelivery/spiegel/pdf/83679144 